\title{
Pengaruh Latihan Incline Push Up Depth Jump Terhadap Hasil Tolak Peluru Gaya Ortodox Siswa Smp Negeri 29 Palembang
}

\author{
Puput Sekar Sari $^{1}$, Dede Dwiansyah Putra ${ }^{2}$, Bayu Iswana ${ }^{3}$, Ardo Okilanda ${ }^{4}$ \\ ${ }^{123}$ Fakultas Keguruan dan Ilmu Kependidikan, Universitas PGRI Palembang, Indonesia \\ ${ }^{4}$ Universitas PGRI Palembang, Indonesia \\ E-mail: sari_puput88@univpgri-palembang.ac.id ${ }^{1}$,dededwiansyahputra@univpgri-palembang.ac.id ${ }^{2}$, \\ bayuiswana-univ.Pgriplg.ac.id ${ }^{3}$, ardo.oku@univpgri-palembang.ac.id ${ }^{4}$
}

Menerima: 05 Oktober 2020; Revisi: 03 Maret 2021; Diterima: 27 April 2021

d https://doi.org/10.24036/ MensSana.06012021.22

\begin{abstract}
The paper aims determine the effect of Incline Push Up Depth Jump exercise toward the results of ortodox-style bullets shot at SMP Negeri 29 Palembang. experimental methods two groups design pre-test post-test. Subjects were 20 male students, 10 students in the experimental group who were treated with the Incline Push Up Depth Jump exercise and the control group 10 people with conventional treatment. Normality test and data homogeneity test applied as the t-test requirement. The results of hypothesis testing using the t test obtained $t_{\text {count }}>t_{\text {table }}(8.86>1.734)$, thus there is an effect of Incline Push Up Depth Jump training on the results of ortodox-style bullet rejection of students of SMP Negeri 29 Palembang. The results of the Incline Push Up Depth Jump traning provide a significant increase because in training the explosive power of the arm muscles is continuously stimulated to become strong, balanced movements need to be considered in training so that together the muscles adapt and improve properly.
\end{abstract}

Keywords: Incline Push Up Depth Jump, Strength, Arm Muscles

\section{Abstrak}

Tujuan penelitian ini adalah untuk mengetahui pengaruh latihan Incline Push Up Depth Jump terhadap hasil tolak peluru gaya ortodox siswa SMP Negeri 29 Palembang. Metode eksperimen dua grup pre-test post test. Subjek berjumlah 20 siswa putra, kelompok eksperimen 10 orang yang diberi perlakuan latihan Incline Push Up Depth Jump dan kelompok kontrol 10 orang dengan perlakuan konvensional. Dilakukan Uji normalitas dan uji homogenitas data sebagai persyaratan analisis uji-t. Hasil pengujian hipotesis menggunakan uji $t$ diperoleh $t_{\text {hitung }}>t_{\text {tabel }}(8,86>1,734)$, dengan demikian terdapat pengaruh latihan Incline Push Up Depth Jump terhadap hasil tolak peluru gaya ortodox siswa SMP Negeri 29 Palembang. Hasil latihan Incline Push Up Depth Jump memberikan peningkatan yang signifikkan karena dalam latihannya daya ledak power otot lengan dirangsang terus menerus untuk menjadi kuat, pergerakan yang seimbang perlu diperhatikan dalam latihan agar secara bersama otot beradaptasi dan meningkat dengan baik.

Kata Kunci : Latihan Incline Push Up Depth Jump, Kekuatan, Otot Lengan

\section{PENDAHULUAN}

Olahraga merupakan sarana untuk mengembangkan sumber daya manusia yang diharapkan mampu menciptakan manusia yang produktif, jujur, sportif, dan memiliki semangat, daya juang dan daya saing yang tinggi (Kumbara, 2019).

Olahraga pada umumnya memiliki tujuan yang berbeda, mulai dari tujuan olahraga sebagai sarana pendidikan, sarana rekreasi, sarana prestasi dan lain sebagainya, semua cabang olahraga memiliki teknik dan tujuan yang berbeda sesuai dari cabang olahraga tersebut.

Setiap cabang olahraga memiliki permasalahannya masing masing, mulai dari masalah pada teknik, kondisi fisik atlet, maupun mental yang dapat merusak penampilan atlet pada cabang olahraga tersebut. Seperti halnya 
cabang olahraga atletik pada nomor tolak peluru, banyak sekali permasalahan yang mucul pada nomor tersebut baik pada teknik, taktik dan mental.

Tolak peluru adalah salah satu cabang olahraga atletik yang gerakannya memberi dorongan atau tolakan terhadap sebuah peluru menggunakan satu tangan dengan permulaan dari pangkal bahu (Sidik, 2010). Tolak peluru merupakan salah satu cabang olahraga atletik yang termasuk dalam nomor lempar (Wiarto, 2013).

Secara teknis, tolak peluru berbeda dengan nomor lempar lainnya, olahraga ini menguji kekuatan atlit untuk menolakkan peluru sejauh mungkin (Jarver, 2005). Disebut tolak peluru karena atlit harus mendorong, bukan melempar, objek berbentuk peluru dengan satu tangan saja (Winendra et al., 2008).

Untuk mendapat hasil yang baik dibutuhkan proses latihan (Sukadiyanto \& Muluk, 2011), Latihan adalah proses tubuh yang tersusun secara sistematis dengan bergerak dan bekerja, dilaksanakan secara terus menerus dan berulang dengan semakin meningkat (Budiwanto, 2012).

Latihan bertujuan untuk membantu para atlet meningkatkan keterampilan dan prestasinya agar semakin maksimal. Untuk tercapainya tujuan tersebut ada beberapa aspek yang perlu diperhatikan, yaitu : latihan fisik (Psyical training), latihan teknik (Tecnical Training), latihan taktik (Tactikal Training) dan latihan mental (Physcological Training) (Tangkudung \& Pusitorini, 2012).

Dalam memperoleh hasil yang baik dan maksimal ketrampilan tolak peluru seseorang harus memiliki kondisi fisik yang baik, seperti hasil penelitian (Nurul, 2015) yang berjudul "Pengaruh Kekuatan Otot Lengan Dan Keseimbangan Terhadap Hasil Tolakan Pada Tolak Peluru Gaya Ortodok Pada Siswa Putra" dapat disimpulkan bahwa faktor kondisi fisik sangat menentukan hasil dari tolakan peluru, maka dari itu untuk membentuk kondisi fisik yang baik sangat diperlukan latihan (Safruddin, 2014), dalam hal ini latihan yang digunakan adalah latihan Incline Push Up Depth Jump.

Incline Push Up Depth Jump merupakan salah satu gerakan yang hampir sama dengan gerakan push up. Akan tetapi ada beberapa perbedaan, diantaranya adalah posisi kaki diatas kotak (box) dan pada saat mengangkat tubuh, posisi tangan dihentakkan hingga berada di atas matras. Tujuan dari latihan ini adalah untuk melatih kekuatan otot lengan dan bahu.

Pada tolak peluru, power merupakan salah satu unsur kondisi fisik yang memiliki peranan penting dalam kemampuan seseorang untuk menghasilkan tolakan yang baik, menurut hasil penelitian (Fitrek Hernado, 2017) menjelaskan bahwa siswa yang memiliki power otot yang baik akan menghasilkan tolakan peluru yang lebih baik pula. Power otot lengan adalah salah satu usaha otot lengan melakukan kerja dengan cepat dan kuat.

Power adalah kemampuan otot dalam mengerahkan kekuatan maksimal dan mengatasi tahanan beban dalam waktu yang sangat cepat (Sukadiyanto \& Muluk, 2011). Power adalah kekuatan jumlah pekerjaan yang bisa dilakukan selama waktu tertentu (Budiwanto, 2012). Waktu tertentu yang dihasilkan dalam hitungan detik dan sangatlah cepat sehingga terlihat seperti kejutan dengan reaksi.

Pada pembelajaran pendidikan jasmani olahraga dan kesehatan di SMP Negeri 29 Palembang untuk cabang olahraga atletik secara khususnya pada nomor tolak peluru, banyak permasalahan yang dihadapi oleh siswa, seperti kesalahan gerak.

Belum dapat maksimal melakukan tolak peluru dan belum sampai kepada jarak lemparan yang diharapkan, serta penguasaan teknik tolak peluru gaya ortodox, yang masih buruk, hal ini terlihat pada melakukan gerakan tolakan gaya ortodox dengan sangat kaku sehingga siswa tersebut lebih nampak seperti melakukan lemparan terhadap peluru bukan melakukan tolakan.

Sehingga dengan teknik yang salah, maka menyebabkan hasil tolakan yang tidak sempurna, maka dari itu munculah ide dari peneliti untuk melakukan eksperimen dalam memperbaiki teknik tolakan, sehingga peneliti menilai perlu adanya metode latihan agar dapat meningkatkan hasil tolak peluru siswa tersebut.

Berikut data tolakan peluru yang dilakukan siswa SMP Negeri 29 Palembang berdasarkan observasi yang dilakukan oleh peneliti pada bulan Desember 2019 di akhir pembelajaran semester agustus Desember 2019.

Tabel 1. Hasil Tolakan Peluru Tes Awal (Pretest) Siswa SMP Negeri 29 Palembang Kelas VIII Putra

\begin{tabular}{ccc}
\hline No & Nama & Tolakan (m) \\
\hline \multicolumn{2}{c}{ KelompokEksperimen } \\
\hline 1 & Alfiansyah & 3.92
\end{tabular}




\begin{tabular}{lll}
\hline 2 & Baran Juned & 3.65 \\
3 & Ersyad Berlian & 3.82 \\
4 & Hendra Saputra & 3.92 \\
5 & Chairul Aminin & 4.11 \\
6 & Lucky Dwi Wahyu & 4.13 \\
7 & M. Hendri Pratama & 3.75 \\
8 & M. Nasrol Firza & 4.05 \\
9 & M. Wahyu K & 4.14 \\
10 & Reza Aryadi & 4.06 \\
\hline \multicolumn{2}{c}{ Kelompok kontrol } \\
\hline 1 & Andrian Mukramin & 3.60 \\
2 & Cristoforus W & 3.80 \\
3 & Edo Febrian & 3.87 \\
4 & Indra Oktafiansyah & 3.76 \\
5 & Koni Asbakdo & 4.03 \\
6 & Andre Manaf & 3.75 \\
7 & M. Irfan Nugraha & 4.12 \\
8 & M. Nauval Audi & 3.87 \\
9 & M. Zakaria & 3.90 \\
10 & Robby Nauval & 4.13 \\
\hline
\end{tabular}

Dari tabel 1 tersebut dapat dikatakan hasil tolakan peluru gaya ortodox yang dilakukan siswa kurang maksimal. hasil pengamatan yang dilakukan pada saat proses pembelajaran dan dikorelasikan dengan hasil tolakan yang kurang maksimal, maka terlihat bahwa permasalahan ini disebabkan oleh kurang maksimalnya metode pembelajaran komando yang diterapkan guru terhadap cabang olahraga atletik nomor tolak peluru dan faktor-faktorlainnya diluar fokus penelitian, metode pembelajaran yang dilakukan guru penjas pada semester agustus Desember 2019 adalah metode komando dimana guru memberikan komando dalam proses pembelajaran.

Wiyono (2017) menjelaskan dalam proses pembelajaran guru sudah menjelaskan secara rinci tentang teknik tolak peluru gaya ortodox dan guru memperagakan proses tolakan yang baik dan benar sehingga siswa dapat memperaktikan gerakan yang dilakukan oleh guru. Berdasarkan hasil tolakan siswa yang kurang maksimal dan kurang maksimalnya metode pembelajaran komando yang dilakukan oleh guru maka peneliti ingin sekali memberi perbaikan atas hasil yang telah di observasi terkait banyaknya kesalahan gerak yang ditemukan peneliti selama pembelajaran berlangsung, dengan sebuah metode yang akan bisa meningkatkan hasil tolak peluru siswa. Kajian dari artikel Okilanda et al., (2020) bahwa sangat besar pengaruh metode latihan terhadap teknik dasar, apalagi ditambahkan dengan faktor pendukung motivasi yang bisa memberi dorongan kuat untuk berlatih. Metode latihan juga memberi dorongan untuk berlatih karena siswa merasakan hal baru yang ditemui dalam latihan.

Sejalan dengan cabang olahraga ini dalam artikel Mariati \& Rasyid (2018) variasi latihan dari metode sirkuit memberi signifikansi peningkatan karena fokus latihan sesuai dengan tujuan peningkatan yaitu pada otot lengan. Sehingga peneliti menarik judul Pengaruh Latihan Incline Push Up Depth Jump Terhadap Hasil Tolak Peluru Gaya Ortodok Pada Siswa Kelas VIII SMP Negeri 29 Palembang.Tujuan peningkatan sesuai dengan dominan otot lengan yang dipakai pada hasil tolak peluru yang dilakukan juga latihan yang memperbaiki kinerja otot lengan dengan cara dan sistem kerja dorongan dari lengan. Tujuan penelitian ini adalah untuk mengetahui ada pengaruh latihan incline push up depth jump terhadap hasil tolak peluru gaya ortodox pada siswa kelas VIII SMP Negeri 29 Palembang.

\section{METODE}

Pada penelitian ini peneliti menggunakan desain quasi experimental design karena dalam penelitian ini terdapat variabel-varibel dari luar yang tidak dapat dikontrol oleh peneliti, selain itu alasan penggunaan desain ini adalah karena pada kenyataannya tidak mudah dalam medapatkan kelompok kontrol yang digunakan untuk penelitian. Dalam suatu sekolah, perguruan tinggi maupun perkantoran misalnya, sering kita temui bahwa tidak mungkin dapat menggunakan seluruh siswa ataupun karyawan yang ada untuk berpartisipasi sebagai sampel karena hanya sebagian yang bisa berpartisipasi sebagai sampel dan sebagaian lagi tidak bisa berpartisipasi sebagai sampel.

Oleh karena itu, untuk mengatasi kesulitan dalam menentukan kelompok kontrol dalam penelitian, maka dikembangkan desain Quasi Experimental, salah satu variabel luar yang mempengaruhi tolakan peluru sisiwa adalah variabel kondisi fisik, seperti kekuatan, daya ledak, dan keseimbangan selain itu variabel lain yang mempengaruhi kemampuan tolakan peluru siswa adalah variabel internal siswa seperti status gizi dan gaya hidup.

Bentuk desain eksperimen ini adalah hasil dari pengembangan true experimental design. 
Desain ini mempunyai kelompok kontrol, tetapi tidak dapat berfungsi sepenuhnya untuk mengontrol variabel-variabel luar yang mempengaruhi pelaksanaan eksperimen. Walaupun demikian, desain ini lebih unggul dari metode pre-experimental design. Desain eksperimen model ini menurut (Arikunto 2009:208) diantarnya sebagai berikut:

a) Time Series Design, Dalam desain ini kelompok yang digunakan untuk penelitian tidak dapat dipilih secara random. Sebelum diberi perlakuan, kelompok diberi pretest sampai empat kali dengan maksud untuk mengetahui kestabilan dan kejelasan keadaan kelompok sebelum diberi perlakuan. Bila hasil pretest selama empat kali ternyata nilainya berbeda-beda, berarti kelompok tersebut keadaannya labil, tidak menentu, dan tidak konsisten. Setelah kestabilan keadaan kelompok dapat diketahui dengan jelas, maka baru diberi treatment/perlakuan. Desain penelitian ini hanya menggunakan satu kelompok saja, sehingga tidak memerlukan kelompok kontrol.

b) Nonequivalent Control Group Design, Desain ini hampir sama dengan pretestposttest control group design, hanya pada desain ini kelompok eksperimen maupun kelompok kontrol tidak dipilih secara random. Dalam desain ini, baik kelompok eksperimental maupun kelompok kontrol dibandingkan, kendati kelompok tersebut dipilih dan ditempatkan tanpa melalui random. Dua kelompok yang ada diberi pretes, kemudian diberikan perlakuan, dan terakhir diberikan postes.

c) Conterbalanced Design, Desain ini semua kelompok menerima semua perlakuan, hanya dalam urutan perlakuan yang berbeda-beda, dan dilakukan secara random

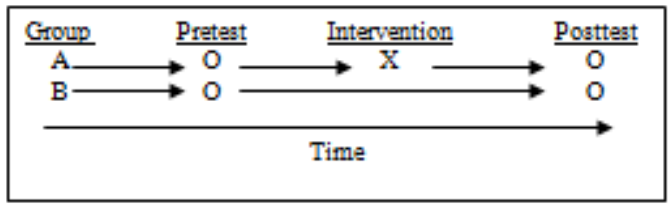

Gambar 1 Metode Eksperimen dua grup

Dari gambar metode eksperimen dapat dilihat metode penelitian ini menggunakan metode pre test dan post tes yaitu terdapat dua kelompok yang keduanya diberlakukan tes awal (Pretest) dan didapatkan data awal penelitian, setelah itu dilakukan perlakuan pada kelompok eksperimen yang berjumlah 10 orang putra dengan perlakukan berupa latihan Incline Push Up Depth Jump yang dilakukan selama 3x perminggu atau 12 kali pertemuan dalam satu bulan latihan, demikian pada kelompok kontrol diberikan waktu latihan yang sama namun tidak diberikan latihan Incline Push Up Depth Jump.

Namun hanya diberikan latihan latihan tolak peluru dengan pembebanan, setelah satu bulan latihan maka dilaksanakanlah pengambilan data akhir atau (post test) dengan melakukan tolakan peluru seperti pada tes awal kepada kedua kelompok tes, sehingga di dapati perbedaan hasil tolakan yang dilakukan oleh kelompok eksperimen dan kelompok kontrol yang memperlihatkan hasil dari kelompok eksperimen lebih baik dari hasil tolakan kelompok kontrol, hasil tersebut dapat dilihat melalui tabel data tolakan siswa berikut ini :

Tabel 2. Hasil Tolakan Peluru Tes Akhir (Posttest) Siswa SMP Negeri 29 Palembang Kelas VIII Putra

\begin{tabular}{lll}
\hline No & Nama & Tolakan (m) \\
\hline \multicolumn{2}{c}{ KelompokEksperimen } \\
\hline 1 & Alfiansyah & 4.57 \\
3 & Baran Juned & 4.32 \\
4 & Ersyad Berlian & 4.48 \\
5 & Hendra Saputra & 4.50 \\
6 & Chairul Aminin & 4.84 \\
7 & M. Hendri Pratama & 5.01 \\
8 & M. Nasrol Firza & 4.63 \\
9 & M. Wahyu K & 5.75 \\
10 & Reza Aryadi & 4.88 \\
\hline
\end{tabular}

\begin{tabular}{lll}
\hline \multicolumn{2}{c}{ Kelompok kontrol } \\
\hline 1 & Andrian Mukramin & 3.68 \\
2 & Cristoforus W & 3.88 \\
3 & Edo Febrian & 3.92 \\
4 & Indra Oktafiansyah & 3.81 \\
5 & Koni Asbakdo & 4.04 \\
6 & Andre Manaf & 3.80 \\
7 & M. Irfan Nugraha & 4.12 \\
8 & M. Nauval Audi & 3.89 \\
9 & M. Zakaria & 3.92 \\
10 & Robby Nauval & 4.07 \\
\hline
\end{tabular}

Dengan teknik pengumpulan data, penulis membagi sampel menjadi dua kelompok (kelompok A dan kelompok B). Kelompok A 
(Eksperiment) diberi perlakuan berupa latihan Incline Push Up Depth Jump hal ini dikarenakan kelompok A atau kelompok ekperiment akan menjadi penentu apakah metode latihan Incline Push Up Depth Jump dapat mempengaruhi hasil latihan tolak peluru menjadi lebih baik lagi dari pada kelompok kontrol dan kelompok B (Kontrol) tidak di beri perlakuan yang sama, namun diberikan latihan latihan tolak peluru biasa yaitu berlatih melakukan tolakan selama $3 x$ seminggu dalam satu bulan untuk menjadi kelompok pembanding antara hasil akhir dari latihan Incline Push Up Depth Jump dengan hasil akhir dari latihan tolak peluru biasa.

Pembagian kelompok ini dilakukan dengan cara random sampling dimana semua populasi memiliki kesempatan yang sama untuk dipilih (Andriani, 2019). Berorientasi pada tujuan penelitian yaitu untuk mengetahui pengaruh latihan incline push up depth jump yaitu variabel bebas $(\mathrm{X})$ terhadap Tolak peluru yaitu variabel terikat (Y). Subjek penelitian ini adalah siswa laki-laki kelas VIII/I sebanyak 20 siswa. Sampel dibagi menjadi dua kelompok eksperimen dan kelompok kontrol. Pengambilan sampel penelitian ini berpedoman pada pendapat yang dikemukakan oleh Arikunto (2010) yaitu dalam menentukan cluster sampel atau sampel kelas harus dipertimbangkan dengan baik sesuai ciri kebutuhan yang ada, sampel penelitian ini diambil dengan pertimbangan khusus yaitu dikarenakan siswa kelas VIII dapat benar benar fokus dalam melakukan latihan, hal ini dikarenakan pada siswa kelas IX semua siswa sudah fokus kepada ujian nasional sehingga peneliti mengantisipasi kurang fokusnya sampel dapat memberikan efek berbeda pada hasil penelitian, demikian dengan siswa kelas VII.

Peneliti memberikan pertimbangan bahwa siswa kelas VII masih dalam tahap proses penyesuaian diri dengan lingkungan sekolah sehingga akan terjadi proses keterhambatan dalam adaptasi lingkungan latihan dengan siswa tersebut sehingga ditakutkan faktor tersebut dapat mempengaruhi hasil penelitian, sedangkan pada siswa kelas VIII, siswa telah beradap tasi dengan lingkungan sekitar, dengan pelatih, dengan sesama siswa dan tidak sedang mempersiapkan ujian nasional sehingga peneliti menyimpulkan bahwa siswa kelas VIII adalah sampel yang potensial untuk melakukan penelitian ini.
Setelah data terkumpul melalui hasil tes latihan Incline Push Up Depth Jump Instrumen tes hasil tolak peluru (variabel Y), kemudian data dianalisis menggunakan rumus korelasional rxy, kemudian untuk menguji nilai $r$ dikonsultasikan ke tabel interprestasi nilai r (Widiastuti \& Pd, 2011).

\section{HASIL DAN PEMBAHASAN Hasil Penelitian}

Data hasil dalam penelitian ini diperoleh dari hasil tes tolak peluru gaya ortodox antara siswa kelompok kontrol dan kelompok eksperimen. Data yang diperoleh bedasarkan hasil tes awal / pre test siswa selanjutnya diadakan proses perlakuan latihan Incline Push Up Depth Jump Selama 1 bulan, 3 kali dalam seminggu pada siswa laki-laki kelas VIII di SMP Negeri 29 Palembang diakhiri tes akhir / posttest.

Tes diberikan untuk melihat hasil tolak peluru gaya Ortodox dengan menggunakan latihan Incline Push Up Depth Jump, Setelah itu didapatkan data rata-rata tolakan kelompok eksperimen lebih besar dari rata-rata tolakan kelompok kontrol yaitu rata-rata tolakan sejauh 4,702 m untuk kelompok eksperimen dan ratarata sejauh 3,913 m untuk kelompok kontrol.

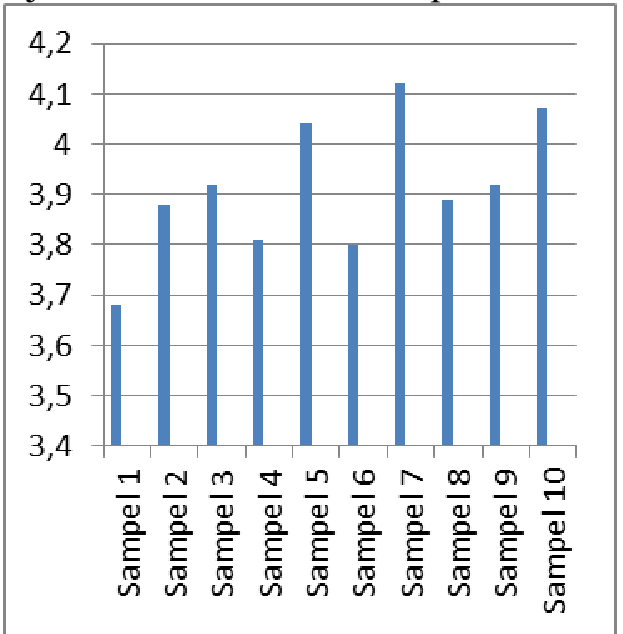

Gambar 2. Diagram Rangkuman Hasil Uji Tes Akhir Tolak Peluru Gaya Ortodox Siswa Pada Kelompok Kontrol

Pada diagram diatas diketahui bahwa hasil tes kelompok kontrol berturut nurut dari sampel 1 sampai sampel 10 adalah $3.68 \mathrm{~m}, 3.88 \mathrm{~m}$, $3.92 \mathrm{~m}, 3.81 \mathrm{~m}, 4.04 \mathrm{~m}, 3.80 \mathrm{~m}, 4.12 \mathrm{~m}, 3.89 \mathrm{~m}$, $3.92 \mathrm{~m}, 4.07 \mathrm{~m}$ dimana rata-rata tolakan untuk kelompok kontrol adalah 3.913m. Dari hasil tersebut memperlihatkan bahwa tolakan siswa 
kelompok kontrol masih tergolong rendah dimana tolakan rata-rata tidak sampai $4 \mathrm{~m}$ yang merupakan jarak tolakan standar siswa SMP yang biasanya mencapai $4 \mathrm{~m}$ jarak rata-rata tolakan.

Selanjutnya adalah dari keduapuluh sampel yang terdiri dari sepuluh kelompok kontrol dan sepuluh kelompok eksperiment maka berikut adalah data tolak peluru gaya ortodox kelompok eksperimen yang sebelumnya telah diberikan latihan Incline Push Up Depth Jump yang dapat dilihat pada diagram Rangkuman Hasil Uji Tes Akhir Tolak Peluru Gaya Ortodox Siswa Pada Kelompok Eksperiment, diagram ini dibuat berdasarkan pengelompokan data yang diambil dari tes akhir dengan melaksanakan tolakan peluru gaya Ortodox pada siswa SMP Negeri 29 Palembang kelompok Eksperiment yang sebelumnya telah diberi perlakuan berupa latihan Incline Push Up Depth Jump yang berjumlah sepuluh orang, data tersebut merupakan data murni dari hasil tes dan dijabarkan berupa diagram yang dapat dilihat pada gambar 3 berikut.

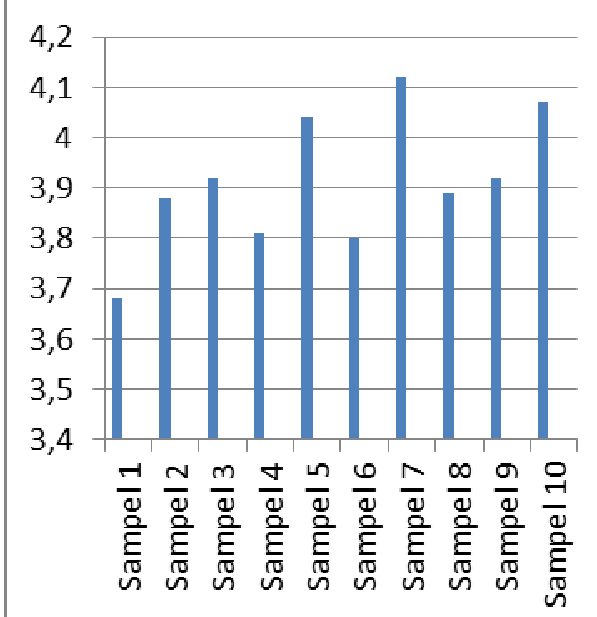

Gambar 3. Diagram Rangkuman Hasil Uji Tes Akhir Tolak Peluru Gaya Ortodox Siswa Pada

Kelompok Eksperiment.

Pada diagram diatas diketahui bahwa hasil tes kelompok eksperimentberturut nurut dari sampel 1 sampai sampel 10 adalah $4.57 \mathrm{~m}$, $4.32 \mathrm{~m}, 4.48 \mathrm{~m}, 4.50 \mathrm{~m}, 4.84 \mathrm{~m}, 5.01 \mathrm{~m}, 4.63 \mathrm{~m}$, $4.75 \mathrm{~m}, \quad 5.04 \mathrm{~m}, 4.88 \mathrm{~m}$. Dari hasil tersebut memperlihatkan bahwa tolakan siswa kelompok eksperiment sudah semakin membaik dimana tolakan rata-rata sudah hapir mendekati angka $5 \mathrm{~m}$ yaitu $4.701 \mathrm{~m}$ yang merupakan jarak tolakan yang cukup bagus untuk siswa SMP.

Pengujian awal dilakukan dengan uji normalitas sampel dengan nilai kolmogorov smirnov untuk data tes awal pretest hasil tolak peluru gaya ortodox siswa SMP 29 Negeri Palembang kelas VIII $\left(\mathrm{X}_{1}\right)$ sebesar 0,132 dengan Asymp. Sig. (2-tailed) $=0,200>0,005$, artinya model latihan Incline Push Up Depth Jump pada tes awal / pre test berdistribusi normal dan memenuhi uji persyaratan analisis data. Sedangkan besaran nilai kolmogrov smirnov data post-test hasil tolak peluru siswa SMP Negeri Palembang kelas XII cabang olahraga atletik $\left(\mathrm{X}_{2}\right)$ sebesar 0,179 dengan Asymp. Sig. (2-tailed) $=0,200>0,05$, yang artinya Incline Push Up Depth Jump pada tes akhir / post-test berdistribusi normal dan memenuhi persyaratan uji analisis data.

Setelah melihat hasil uji normalitas data dinyatakan normal. Selanjutnya dilakukan pengujian homogenitas diketahui Sig $=0,031$ lebih besar daripada taraf signifikansi $5 \%$ hal ini ditunjukkan dengan Sig $>0,05$. Karena $\mathrm{Sig}=$ $0,031>0,05$ Nilai Levene 5, 469. Hasil tes akhir kelompok eksperimen dan kelompok kontrol dengan nilai tes akhir / post test kelompok eksperimen nilai maksimal $=5,04$, nilai minimal $=4,32$ dan nilai rata-rata 4,701 dan nilai standar deviasi 0,240 .

Nilai tes akhir / post test kelompok kontrol dengan nilai maksimal $=4,12$, nilai minimal $=3,68$ dan nilai rata-rata $=3,913$ dan nilai standar deviasi $=0,134$. Setelah data terkumpul melalui hasil tes awal dan tes akhir latihan Incline Push Up Depth Jump atau (variabel X) dan hasil tolak peluru (variabel Y), kemudian data dianalisis menggunakan rumus: $\mathrm{Y}$ $=\mathrm{a}+\mathrm{b} X$ dimana $\mathrm{Y}$ merupakan Subjek variable terikat yang diproyeksikan, $\mathrm{X}$ adalah Variabel bebas yang menpunyai nilai tertentu untuk diprediksikan a adalah nilai konstanta harga $\mathrm{Y}$ dan $b$ adalah penentu arah sebagai penentu prediksi penelitian.

Disrtibusi tabel t untuk $\alpha=0,05$ dan derajat kebebasan ( $\mathrm{dk}=\mathrm{n}-2)$. Kaidah Keputusan : Jika $t_{\text {hitung }}>t_{\text {tabel }}$ berarti hipotensi Ha di terima, sedangkan harga lainnya hipotesis Ho yang diterima. Data dalam penelitian ini diperoleh dari hasil tes tolak peluru gaya ortodox antara siswa kelompok kontrol dan kelompok eksperimen. Data yang diperoleh bedasarkan hasil tes siswa setelah diadakannya proses latihan Incline Push Up Depth Jump Selama 1 bulan, 3 kali dalam seminggu pada siswa laki-laki kelas VIII.I di SMP Negeri 29 Palembang. Tes diberikan untuk melihat hasil tolak peluru gaya Ortodox dengan menggunakan latihan Incline Push Up Depth Jump 
Data tes diperoleh dari hasil kemampuan dua kelompok, yaitu kelompok eksperimen dan kelompok kontrol. Untuk membandingkan hasil tolak peluru gaya ortodox antara siswa laki-laki kelas eksperimen yang diberikan latihan Incline Push Up Depth Jump, dan kelas kontrolyang tidak diberikan latihan Incline Push Up Depth Jump. Analisa data statistik di dalam penelitian ini digunakan oleh penelitian unuk melihat hasil tolak peluru gaya ortodox pada siswa SMP Negeri 29 Palembang. Dalam melakuka analisa data statistik, penelitian menggunakan beberapa metode statistik yaitu regresi linear sederhana, korelasi produck moment, dan mengujikan hipotesis digunakan uji t.

Analisa melalui regresi linear sederhana dengan mencari persamaan regresi yaitu :

$$
\overline{\mathrm{Y}}=\mathrm{a}+\mathrm{bX}
$$

Dimana :

$$
\begin{aligned}
\overline{\mathrm{Y}} \quad= & (\text { Dibaca Y Topi) Subjek Variabel } \\
& \text { terikat yang diproyeksikan } \\
\mathrm{X} \quad= & \text { Variabel bebas yang mempunyai } \\
& \text { nilai tertentu untuk diprediksikan } \\
\mathrm{a} \quad= & \text { Nilai konstanta harga Y jika } \mathrm{X}=0 \\
\mathrm{~b} \quad= & \text { Nilai arah sebagai penentu prediksi } \\
& \text { yang menunjukan nilai penngkatan } \\
& (+) \text { atau nilai penurunan }(-)
\end{aligned}
$$

Dari data yang ada selanjutnya dilakukan perhitungan korelasional untuk melakukan perhitungan korelasi antara Latihan Incline Push Up Depth Jump Terhadap Hasil Tolak Peluru Gaya Ortodox sehingga perhitungan tersebut didapatkan nilai a sebesar 3,91, Jadi persamaan regresi yang diperoleh yaitu :

$$
\begin{array}{ll}
\overline{\mathrm{Y}} & =\mathrm{a}+\mathrm{bX} \\
\overline{\mathrm{Y}} & =3,91-0,79 \mathrm{X}
\end{array}
$$

Berdasarkan persamaan regresi yang telah diperoleh, diketahui bahwa nilai $b$ yang merupakan koefisien regresi bernilai positif yaitu 0,79 hasil nilai positif ini menunjukan bahwa diprediksikan terdapat pegaruh latihan Incline Push Up Depth Jump terhadap hasil tolak peluru siswa gaya ortodox. Dengan demikian dapat dipastikan bahwa rata-rata hasil kemampuan tolak peluru siswa kelas eksperimen lebih tinggi dari kelas kontrol. Ini dapat dilihat dari regresi jika nilai variable $\mathrm{X}$ disubtitusikan kepersamaan regresi tersebut.
Analisis selanjutnya adalah menggunakan korelasi product momen analisis ini digunakan untuk melihat besarnya pengaruh dari pengaruh latihan berjalan Incline Push Up Depth Jump tehadap hasil tolak peluru gaya ortodox. Berdasarkan perhitungan koefisien product moment didapatkan hasil sebesar 0,90 dengan kategori tingkat hubungan (antara variabel bebas dengan variabel terikat) kuat. Dengan demikian untuk mengetahui besarnya pengaruh atau kontribusi penerapan variabel $\mathrm{X}$ terhadap variabel $\mathrm{Y}$ dapat dihitung sebagai berikut $\mathrm{r}^{2} \mathrm{x}$ $100 \%=(0,90)^{2} \times 100 \%=81 \%$. Dari hasil tersebut dapat disimpulkan bahwa besarnya pengaruh (kontribusi) latihan pengaruh latihan Incline Push Up Depth Jump (variabel bebas) terhadap hasil tolak peluru gaya ortodox (variabel terikat) sebesar $81 \%$ selebihnya di pengruhi oleh faktor lain.

Seperti yang telah ditentukan di atas berdasarkan analisis regresi linier sederhana menunjukkan (diprediksikan) adanya pengaruh pengunaan latihan Incline Push Up Depth Jump terhadap hasil tolak peluru gaya ortodox. Juga analisis melalui korelasi product moment menunjukkan besarnya pengaruh atau kontribusi variabel bebas terhadap variabel terikat sebesar $81 \%$, maka melalui uji hipotesis dapat dilihat apakah yang ditimbulkan tersebut signifikan atau tidak dengan ketentuan kriteria pengujian hipotesis.

Selanjutnya dilakukan perhitungan t-tes sehingga perhitungan tersebut diperoleh nilai $t_{\text {hitung }}$ sebesar 8,86, dengan demikian, berdasarkan kriteria hipotesis dalam penelitian ini maka dapat dipastikan bahwa ada pengaruh latihan Incline Push Up Depth Jump terhadap hasil tolak peluru gaya ortodox pada siswa SMP Negeri 29 Palembang dikarenakan Ho Tertolak. Dengan taraf uji yang digunakan adalah satu pihak dan signifikan dengan taraf $\alpha=0,05 \mathrm{dan} \mathrm{dk}$ $=\mathrm{n}-2$ maka $20-2=18$, sedangkan untuk $\mathrm{t}_{\text {tabel }}$ dapat dilihat dalam lampiran distribusi nilai $t$ maka diperoleh $t_{\text {tabel }}=1,734$ (dalam lampirn distribusi nilai $t$ ).

Dari data di atas dapat disimpulkan bahwa hipotesis Ha dapat diterima atau $t_{\text {hitung }}>t_{\text {tabel }}(8,86$ $>1,734)$. Dengan demikian terdapat pengaruh latihan Incline Push Up Depth Jump terhadap hasil tolak peluru gaya ortodox pada siswa SMP Negeri 29 Palembang. 


\section{Pembahasan}

Kelas yang digunakan sebagai sempel penelitian ini adalah secara cluster sempel dan dikelompokan menjadi dua kelompok yaitu kelompok eksperimen dan kelompok kontrol, dengan jumlah 10 siswa kelompok kontrol dengan jumlah 10 siswa kelompok eksperimen, ke dua kelompok tersebut diberikan latihan yang berbeda yaitu kelompok eksperimen diberikan latihan Incline Push Up Depth Jump dan kelompok kontrol tidak diberikan latihan. Dalam pengumpulan data, peneliti menggunakan metode tes dan pengukuran dilakukan secara praktek langsung di lapangan berupa tes tolak peluru. Penelitian mengambil tes awal tolak peluru gaya Ortodox, bertujuan untuk melihat kemampuan dasar sebelum diberikan latihan Incline Push Up Depth Jump terhadap hasil tolak peluru gaya Ortodox pada siswa SMP Negeri 29 Palembang. Adapun teknik pegumpulan data yang digunakan dalam penelitian ini adalah teknik tes. Pemberian tes untuk masing-masing siswa diberikan 3 kali kesempatan, di mana hasil tes diambil nilai yang terbaik.

Penelitian ini bertujuan untuk mengetahui pengaruh latihan Incline Push Up Depth Jump terhadap Hasil tolak peluru gaya ortodox. Melalui latihan ini diharapkan dapat meningkatkan kemampuan tolak peluru gaya ortodox siswa, sehingga lebih memotivasi siswa untuk latihan dan hasil kemampuan mereka meningkat pula.Pengumpulan data berupa observasi dan tes. Observasi di sini untuk mengetahui kemampuan tolak peluru siswa pada saat penggunaan latihan Incline Push Up Depth Jump sekaligus sebagai data pendukung penelitian. Untuk mengumpulkan data hasil kemampuan siswa, peneliti menggunakan tes. Tes dilakukan pada awal dan akhir pertemuan.

Dari hasil tes awal kelas ekseperimen menunjukkan rata-rata hasil tes kemampuan tolak peluru gaya ortodox siswa sebesar 3,89 meter, sedangkan kelompok kontrol rata-rata sebesar 3,87 meter. Setelah kelompok eksperimen diberi perlakuan berupa latihan Incline Push Up Depth Jump selama 12x pertemuan menunjukkan peningkatan hasil kemampuan tes tolak peluru dengan rata-rata yaitu 4,70 meter, lebih tinggi dibandingkan kelompok kontrol yang tidak diberikan perlakuan dengan hasil kemampuan tes rata-rata yaitu sebesar 3,92 meter.

Berdasarkan hasil diatas maka dapat kita lihat bahwa latiahan Incline Push Up Depth
Jump dapat mempengaruhi hasil tolakan peluru siswa secara maksimal, hal ini dikarenakan dengan latihan Incline Push Up Depth Jump otot dipaksa untuk bekerja keras sehingga menyebabkan hypertropy otot yang membuatnya semakin kuat dan semakin padat sehingga dapat memperkuat tolakan atlet.

\section{KESIMPULAN}

Berdasarkan hasil penelitian, dapat diambil kesimpulan bahwa terdapat perbandingan nilai latihan Incline PushUp Depth Jump terhadap hasil tolak peluru gaya ortodox pada siswa SMP Negeri 29 Palembang. Hasil tes akhir kelas eksperimen menunjukkan rata-rata hasil tes kemampuan tolak peluru gaya ortodox siswa sebesar 4,01 meter, sedangkan kelompok kontrol rata-rata sebesar 3,91 meter sehingga dapat disimpulkan bahwa siswa yang diberi latihan Incline PushUp Depth Jump dapat meningkatkan kemampuan tolakannya.

Pada penelitian ini peneliti hanya melakukan kontrol pada metode latihan saja tanpa melakukan pengontrolan pada aspek lainnya seperti pola makan, pola istirahat, motivasi atau lainnya, namun pada pengontrolan latihan saja latihan Incline PushUp Depth Jump sudah memperlihatkan perbedaannya dengan latihan konvensional apalagi jikalau peneliti melakukan kontrol pada aspek lainnya. Diharapkan untuk peneliti selanjutnya agar dapat melakukan pendalaman terhadap penelitian ini dan dapat melakukan kontrol pada variabel lainnya agar didapatkan informasi terbarukan tentang latihan Incline PushUp Depth Jump beserta variabel lainnya yang mempengaruhi.

\section{DAFTAR PUSTAKA}

Akdon, dan Ridwan. (2009). Aplikasi Statistika dan Metode Penelitian Untuk Administrasi dan Managemen. Dewa Ruchi: Bandung.

Andriani, D. P. (2019). Metode Sampling.

Arikunto, S. (2010). Prosedur Penelitian Suatu Pendekatan Praktik. 2010. Jakarta: Rineka Cipta.

Budiwanto, S. (2012). Metodologi Latihan Olahraga. Malang: Universitas Negeri Malang. 
Pertiwi, Eka Diana. (2016). Pengaruh Latihan Depth Jump, Knee Tuck Jump dan Jump To Box Terhadap Power Tungkai Pada Atlet Bolavoli Klub Putra Mustika Blora. Skripsi Universitas Negeri Semarang.

Handayani, H. Y. (2019). Survei Tingkat Kebugaran Jasmani Mahasiswa Pendidikan Olahraga Angkatan 2017 Stkip Pgri Bangkalan. Halaman Olahraga Nusantara (Jurnal Ilmu Keolahragaan), 2(1), 40-49.

Homan, M., dan Miller, L. J. (2008). Coaching in organizations: Best coaching practices from the Ken Blanchard Companies. John Wiley \& Sons.

Jarver, J. (2005). Belajar dan berlatih atletik. Bandung: CV. Pionir Jaya.

Joulia, F., Steinberg, J. G., Faucher, M., Jamin, T., Ulmer, C., Kipson, N., \& Jammes, Y. (2003). Breath-hold training of humans reduces oxidative stress and blood acidosis after static and dynamic apnea. Respiratory Physiology \& Neurobiology, 137(1), 19-27.

Kumbara, H. (2019). Survei minat member yang mengikuti fitness pada pusat kebugaran kota palembang. Halaman Olahraga Nusantara (Jurnal Ilmu Keolahragaan), 2(2), 122-129.

Lumintuarso, R. (2013). Pembinaan multilateral bagi atlet pemula. Universitas Negeri Yogyakarta.

Mariati, S., dan Rasyid, W. (2018). Pengaruh Metode Latihan Sistem Sirkuit Terhadap Peningkatan Kemampuan Daya Ledak Otot Lengan Pada Atlet Bolabasket Fik Unp. Jurnal MensSana, 3(2), 28-36.

Mashud, M. (2018). Analisis Masalah Guru PJOK Dalam Mewujudkan Tujuan Kebugaran Jasmani. Analisis Masalah Guru PJOK Dalam Mewujudkan Tujuan Kebugaran Jasmani.

Okilanda, A., Dlis, F., Humaid, H., dan Putra, D. D. (2020). Perbedaan Pengaruh Metode
Latihan Dan Motivasi Berlatih Terhadap

Teknik Dasar Sepakbola Sekolah Sepakbola Beji Timur U-13. Jurnal Educatio FKIP UNMA, 6(1), 80-89.

Sahri, Januar. dkk. 2020. Implementation Analysis of Digitally Pencak Silat Agility Instrument. Jurnal: EKSAKTA Berkala Ilmiah Bidang MIPA Volume 21 No 02. 2020 pp 139-147, ISSN : Print 1411-3724 - Online 2549-7464, DOI

https://doi.org/10.24036//eksakta/vol 21-iss2/226.

Sidik, D. Z. (2010). Mengajar dan melatih atletik. Bandung: PT Remaja Rosdakarya.

Sukadiyanto dan Muluk, D. (2011). Pengantar teori dan metodologi melatih fisik. Bandung: Lubuk Agung.

Tangkudung, J., dan Pusitorini, W. (2012). Coaching Sports Achievement Achievement edition II. Jakarta: Smart Jaya.

Wiarto, G. (2013). Atletik. Yogyakarta: Graha Ilmu.

Widiastuti, W., dan Pd, M. (2011). Tes dan pengukuran olahraga. Jakarta: PT. Bumi Timur Jaya.

Winendra, A., Kharisma, J., \& Joe, M. (2008). Atletik. Yogyakarta: Pustaka Insan Mandiri. 